\title{
Factors Influencing the Perfomance of Microfinance Insttutions: A Case Study of Meru County
}

\section{Lydia Kagwiria Kirika}

Meru university of science and technology, Kenya lydiahkagwiria14@gmail.com

\begin{abstract}
The main goal of every Microfinance Institution (MFI) is to operate profitably in order to maintain its stability and improve growth and sustainability. This study focused on the factors influencing MFIs financial performance in Mere County. In every market there is increased competition from the various player in the market with an aim of convincing customers to purchase their products and services, this has not been an exception in micro finance institutions, thus the study objectives was to determine factors influencing microfinances performance. There are various sources of the reviewed literature such as National micro \& small enterprises baseline (1999), Ministry of devolution \& planning (May 2013) Meru county development profile among others as indicate in references.

The study applied survey research using descriptive approach in order to find out or enquire the state of affairs that exist at present that causes this effect. The study was carried out in Meru Town and some of the micro finances such as SMEP, FAULU, KWFT, located in Meru were used in data collection by using simple random sampling to select the sample to be used, the target population was 956 which was minimized to a sample size of 274 - Questionnaires were used in Data collection to gather the information which was directed to customers, credit managers and the branch manager of the various micro finances. After the data collected it was be analyzed by first coding by assigning numerical values to make them quantitative. Tables and pie charts were used in presentation of data, frequency distribution tables was used to show the number of respondents and their views for easier analysis. The findings and conclusion of this study are likely to be useful to micro finances and other scholars.
\end{abstract}

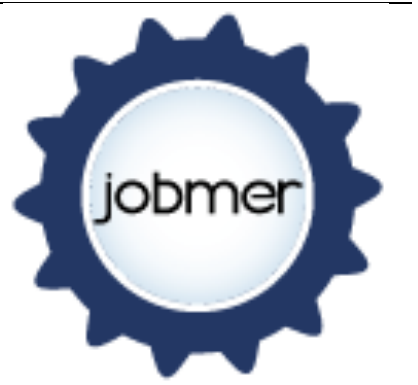

Journal of Business

Management and Economic Research

Vol.2, Issue.6, 2018

pp.33-41 Doi: $10.29226 /$ TR1001.2018.40

Keywords: Microfinance,loan repayment, interest rates, small medium enterprise, collateral 


\section{Background}

Global financial markets and systems have experienced a very impressive growth over the Last few decades. This has been accompanied by an evolution also in the business practices in countries around the world. In the financial sector there has been a development of various new financial instruments and techniques to meet changes in the constantly changing business environment. The financial institutions have been able to create various innovative products for different sectors in the market. Through the various capabilities to create innovative products, financial products have been able to create and maintain economic performances countries around the world. As a result of these changes in the financial sector and business world there is an arising importance and research interest in financial institutions in banking institution (Ho, 2002)

Microfinance originated in 1976 in Bangladesh by Dr.Mohammed Yunshan he started microfinance scheme as part of an experiment in the rural areas. The scheme later became the Grameen Bank which has created the way for many microfinance banks and institution all over the world. Dr Mohammed Yunus was awarded the Nobel Peace Prize for these efforts of trying to eliminate poverty through the use of microfinance (Bateman, 2014). The nature of microfinance has changed over the years and depending on a country, the goal of players and their activities is no longer only for social economic development but some are out for profit. They are no longer 'non-profit' organizations but businesses that are aimed at making a profit at member's expenses. The microfinance industry has many players in it and the industry experiences a lot of changes in regulation and policies (Robinson, 2001).

(Robinson, 2001) The experiment done by Dr. Yunus evolved into the Grameen Bank which became the first microfinance institution in the world. Their operation popularized a system of group lending, where loans were given to individual members of homogeneous groups, then members of the group would guarantee each other. The members would not get any further credit if any member defaulted in payment. This in turn created the incentive to pay the loans that were issued. The loans did not have any collateral so they became very popular among the people without anything to use as collateral.

This microfinance model began to spread globally, especially in developing countries (Roy, 2009).Habibu (2010) and John (2011) noted in their respective studies that (2010) and John (2011) noted in their respective studies that MFIs loans had increased the income in most owners and poor individuals in Bangladesh and Zimbabwe respectively. Both studies focused on business performance in areas such as acquisition of assets and increased sales.

In Kenya on 2ndMay 2008, the Microfinance Act gave the microfinance institution the ability to take deposits as opposed to before where the microfinance institution did not have the ability to take up deposits and had to be dependent on other financial institution such as banks. Most microfinance institutions applied for license and were now able to take up deposits from the general public. The term microfinance was replaced by microfinance bank following further amendments on the Act in 2013.

The new licensed by the central bank to provide all types of financial services which included savings and credit (Central Bank of Kenya, 2008).In a report done by Central bank of Kenya (2013), it revealed that there are presently about nine deposit-taking microfinance banks that are operating Kenya. 
Some MFIs have not changed to DTMBs due to tough conditions placed by the CBK.The strict requirements have seen those MFIs that converted experience an enormous reduction in earnings which has led to the discouraging of other players to transform. The reason for transforming to a deposit taking microfinance was to enable the MFIs to be able to access cheaper funds. This would help them be able to lend to the public at much lower rates as opposed to when they depended on other financial institution which are more expensive leading to high interest rates on their clients.

The major goal of deposit taking micro finance banks is to enable the low income earners to have an opportunity in which they can become self -sufficient through opportunities of being able to save money, borrowing money and accessing insurance. Most clients of the Microfinance institutions are low incomes earners who have limited access to major financial services and the products provided by DTMBs enable this type of client to access credit and banking service which he or she cannot be able to access in main stream banking. These services are such loans, savings, insurance and remittances (IMF, 2011).

In Kenya Micro finances are seen as potential institution to provide credit \& other financial services for poverty eradiation ,about $60 \%$ of the population are poor \& out of the scope of formal banking service, according to ( National micro \& Small enterprises Baseline Survey 1999). There are close to 1.3 million MSEs employing nearly 2.3 million people that is $20 \%$ of the country's total employment ,contributing $18 \%$ of the overall GDP \& $25 \%$ non-Agricultural GDP.Despite this important contribution only $10.4 \%$ of the MSEs receive credit \& other financial service. The formal banking sector (mainstream banks) in Kenya over the years has regarded the informal sector as risk \& not commercially viable (Omino 2005)

According to the ( poverty reduction strategy paper PRSP of 1999) a large number of Kenyans drive their livelihood from MSEs, however in spite of the importance of this sector ,it shows that provision \& delivery of credit \& other financial services to the sector by mainstream banks has been below expectations which means the poor have difficult to climb out of poverty due to lack of finance for their productive activities. Thus new innovative \& pro- poor mode of financing low income households \& MSE's based on sound operating principle need to be developed (Omino 2005 ).

Micro finance fill a needed gap with the financial service industry by offering small loans or micro credits to people unable to access conventional loan service. Those living in under-developed areas can access needed financial resources through the service provided by micro finances. Micro finances established using NGO or a saving \& credit co-operative societies framework have been important source of credit to low income households \& MSE's in rural \& urban areas who lack collateral to access loans from Mainstream banks ( National micro \& small enterprise baseline 1999 ) .this micro finance institution are regulated by micro finance Act $2006 \&$ the regulation issued there under sets out the legal regulatory \& supervisory framework, this Act became effective $2^{\text {nd }}$ may 2008 with the principle aim of regulating the establishment business \& operation. According to ( central bank of Kenya 2013 ). The Act enables deposit taking by micro finance licensed by central bank of Kenya to mobilize savings from general public thus promoting

\section{Problem statement}

Microfinance institutions play a significant role in Kenya and the growth of the economy. With continuous economic growth, it is important there is need for finance to help in the enhancing and growth of business. The poor need financing to help them be able to grow their business and this 
can be achieved through the microfinance funding. Kenyan informal sector is constitutes of 6.4 million people (CBK 2010).

Despite efforts by various microfinance institutions, Kenya Women's Finance Trust (KWFT), K-Rep, Family Finance, Equity Bank and others to improve the banking of the people through microfinance, the industry has not shown any sign of growth and expansion (Kenya Economic Survey, 2009). The interest rates charged by financial institution such as commercial Banks, microfinance institutions and other financial institutions in Kenya have been high. This has caused a lot of criticism with people shying away from financing options due to the high interest rate

Despite efforts by the movement through the CBK to bring them down, the rates have still remained high. These high interest rate changes have had negative impacts on the economy. The effect of this has been the reduction of the value of disposable income in the country. This has made it difficult for people seeking funding so as to be able to access affordable funding. Most studies and research conducted in this area of microfinance, focused on different perspectives rather than effect of interest rates on microfinance institutions 'products thus pointing out the need to pursue this study. Such studies include Nyawach(2011); Chelogoy, Anyango and Odembo (2004); Kanyinga and Mitullah (2007) with the studies dealing with the exploitive practice by banks and micro finance through expensive interest rates. These studies are limited because they did not look into the effect on the interest rates on the microfinance institutions 'products and how these changes affect the decision of a person seeking finance.

\section{Research objective}

The general objective of this study was to establish the factors influencing the performance of microfinance institution in Meru town Kenya.

\section{Research methodology}

This study adapted survey research using descriptive approach to answer study questions. According to Orodho (2003) descriptive survey is a method of collecting data by interviewing or administration of questionnaires to a sample of individuals. Descriptive research is used to describe characteristics of population or phenomenon being studied (Shields, Patricia and Rangarjan, N 2013). A descriptive study is undertaken in order to ascertain and to be able to describe the characteristics of the variables in a situation. Danielle Joynson (2014) descriptive study has several advantages like; it uses qualitative and quantitate data in order to find the solution to whatever is being studied, it also in understanding the characteristics of group in a given situation. Zikmundy Bobin (2010) says that descriptive research is to describe characteristics of objects people, groups, organisations or environment.

\section{Findings of the study}

The number of questionnaires that were administered to all the respondents was 280 questionnaires. A total of 256 questionnaires were properly filled and return from the microfinance employees and members. This represented an overall successful response rate of $92 \%$. According to Mugenda and Mugenda (2003), a response rate of $50 \%$ or more is adequate. 
Lydia Kagwiria Kirika, 2018, Vol.2, Issue.6, pp.33-41

Table 4.1 Response rate

\begin{tabular}{lcc}
\hline Response rate & frequency & percent \\
\hline Returned & 252 & $90 \%$ \\
Unreturned & 28 & $10 \%$ \\
Total & 280 & $100 \%$ \\
\hline
\end{tabular}

Source; survey data 2018

\section{Demographics}

The preliminary information gathered regarding the characteristics of the respondents was about microfinance name.

\section{Microfinance name}

The respondents were asked to indicate the name of their microfinance. Table 4.2 shows that $41.8 \%$ of the respondents were from KWFT, 26.4\% SMEP and 31.8\% FAULU BANK.

Table 4.2 Microfinance name

\begin{tabular}{lcc}
\hline Microfinance Name & Frequency & percent \\
\hline KWFT & 117 & 41.8 \\
SMEP & 74 & 26.4 \\
FAULU BANK & 89 & 31.8 \\
Total & 280 & 100 \\
\hline
\end{tabular}

Source; survey data 2018

Credit management and financial performance

Table 4.3 Credit management

\begin{tabular}{lcc}
\hline Credit officers and customer's views & frequency & percent \\
\hline Laid down policies are followed & 244 & 87 \\
Credit is checked if it was administered as per the guideline & 199 & 71 \\
Defaulters are listed with the CRB & 156 & 56 \\
Credit repayment is checked monthly & 230 & 82
\end{tabular}

Source; survey data 2018 


\section{Descriptive analysis for credit management}

The first study question was to determine ways in which credit management affect microfinances financial performance in Meru town. Table 4.3 shows that $87 \%$ of the respondent said that laid down policies are followed when giving credit, $71 \%$ said that credit is checked if it was administered as per the guideline, $82 \%$ said that credit repayment is checked monthly and $56 \%$ said that defaulters are listed with the CRB.

\section{Pricing policy, Investment decision and finance performance}

Table 4.4 Pricing policy and investment decision

\begin{tabular}{lcc}
\hline Branch manager's opinion & agreed & disagreed \\
\hline Stock market highly preferred & 2 & 1 \\
Impact of carving & 2 & 1 \\
Short term investment money market & 1 & 2 \\
Investment decision scrutinized before implementation & 2 & 1 \\
Surplus funds invested in income generating avenues & 2 & 1
\end{tabular}

Source; survey data 2018

\section{Descriptive analysis for investment decision and pricing policy}

The second study question was to investigate ways in which pricing policy and investment decisions affect microfinance financial performance. Out of the three branch managers interviewed majority agreed that stock investment are highly preferred, majority agreed that the carving as an impact in their financial performance, majority disagreed that short term investment are preferred, 2 managers agreed that investment decisions are scrutinized before implementation and majority agreed that surplus funds are invested in income generating avenues.

\section{Competition from commercial banks and financial performance}

Table 4.5 Competition

\begin{tabular}{lcc}
\hline Branch managers views & agreed & disagreed \\
\hline Commercial banks threat & 1 & 2 \\
Banks more liquid & 2 & 1 \\
Microfinances depend on banks & 2 & 1 \\
\hline
\end{tabular}

Source; survey data 2018 


\section{Descriptive analysis for competition}

The researcher wanted to find out the effect of competition from commercial banks on financial performance of microfinances. Table 4.5 shows that 2 out of the 3 manager's interview disagreed that commercial banks are threat to microfinances financial performance, 2 managers said that banks are more liquid than Microfinances and 2 agreed that microfinances depend on commercial banks.

\section{Repayment period and collateral and financial performance}

Table 4.6 Collateral and period

\begin{tabular}{lcc}
\hline Customer's opinion & frequency & percent \\
\hline Interest rates & 167 & 68 \\
Repayment period & 125 & 51 \\
Requirements are many & 199 & 81 \\
\hline
\end{tabular}

Source; survey data 2018

\section{Descriptive analysis for repayment period and collateral}

The fourth and last the study question was to establish ways in which repayment period and collaterals affect microfinances financial performance. Table 4.6 shows that $68 \%$ said that interest charged are too high, 51\%agreed that repayment period is short. Finally, $81 \%$ said that the requirements access loans are too many and the process is long The number of questionnaires that were administered to all the respondents was 280 questionnaires. A total of 256 questionnaires were properly filled and return from the microfinance employees and members. This represented an overall successful response rate of $92 \%$. According to Mugenda and Mugenda (2003), a response rate of $50 \%$ or more is adequate.

Table 4.1 Response rate

\begin{tabular}{llc}
\hline Response rate & frequency & percent \\
\hline Returned & 252 & $90 \%$ \\
Unreturned & 28 & $10 \%$ \\
Total & 280 & $100 \%$ \\
\hline
\end{tabular}

Source; survey data 2018 


\section{Summary of the findings}

The summary was done in line with the objectives of the study based on the output of the descriptive analysis.

The study sought to establish the extent to which credit management influence microfinances financial performance .Descriptive analysis was conducted and the results indicated that laid down policies are followed when giving credit and they are reviewed annually. In addition respondent said that credit repayments are checked monthly and defaulters are listed with the CRB.

Descriptive analysis for pricing policy and investment decision was conducted and the findings indicated that microfinances invested surplus funds in income generating avenues, microfinances also invested its funds in stock market and investment decisions are scrutinized before they are Implementation.

The results also indicated that there was low competition from commercial banks. The employees also agreed that banks are more liquid than microfinances in terms of huge credit and microfinances depend on commercial banks.

The findings on repayment period and collaterals indicated that microfinances higher interest than the commercial bank. Result further indicated that repayment period is very short and the requirements are many and the process is long.

\section{Conclusion}

\section{Credit management and financial performance}

The study concluded that there were effective credit management policies at the microfinances governing credit or loan issuing. This because the credit officers said that laid down polices are followed when giving loans and action is taken for the defaulters to ensure effective loan repayment.

\section{Pricing policy, Investment decision and financial performance}

The study concluded that there was good and effective investment decisions which led to increased financial performance of microfinances owned by business groups and employed workers. It was possible to infer that holding other factors constant investment decisions were found to have a positive and significant relationship with financial performance of microfinances.

\section{Competion from commercial banks and financial performance}

The study concludes that competition from commercial banks was low this led to improved financial performance of microfinances due to their flexibility. It can be concluded that when holding other factors constant competition was found to have a positive and significant relationship with financial performance of microfinances.

\section{Repayment period, collateral and financial performance}

The study concludes that the interests charged by microfinances are too high. It can also be concluded that repayment period and collaterals required have a significant effect on microfinances financial performances. 


\section{Recommendations}

The study recommends that microfinances should review loans repayment regularly, ensure proper loan appraisal and educate members on loan repayment before loan disbursement.

The study recommends microfinances to establish effective investment policies so as to attract and encourage large institutions and foreign investors to participate. They should also develop a risk appetite index and involve financial experts in investment decisions.

The study recommends microfinances to ensure competition from commercial banks is managed well and minimize their dependent on commercial banks.

The study recommends that microfinances should reduce their loan requirement and charge affordable rates to attract more customers thus helping improve their liquidity hence increasing financial performance.

\section{References}

Abir \& C. (2010) Factors Influencing new product Development in Micro Finance institution Indian institute of management Lucknow: India.

Andrew B.Abel. (2010).Macroeconomics (5 $5^{\text {th }}$ Ed).Dorling Kindersley: India Pvt.Ltd

Government of Kenya (2005) "Development of micro finance \& small enterprises For healthy \& employment creation for poverty eradication" -Session Paper 2.

Central bank (2009), Report on growth of banks I Kenya.

Central bank of Kenya.(2013). Available from https:// WWW.centralbank.go.ke

Fornell, E,( 1992). A national customer satisfaction Barometer; (pp 1-21). The Swedish experience Journal of Marketing

Michael , T . \& Miles, G. (2004). Financial Performance of Microfinance Institutions Journal of Microfinance.6, 41

Amidu, M. (2006). Determinants of dividend payout ratios in Ghana the Journal of Risk Finance. 7, 136-145.

Anthony, D. (2005). Cooperation in microcredit borrowing groups: Identity, sanctions, and reciprocity in the production of collective goods. American Sociological Review, 70(3), 496-515.

John, s. \& S.Arnold (2010).Financial Exclusion in Kenya: Examining the changing Picture, 20062009. Financial inclusion in Kenya

Kothari, CR (2004). Research Methodology (2nd Ed) .New Delhi: New age International limited.

Mark W.Johnson (2010).Business model innovation for growth \& Renewal Frog Design

Gisemba, P.N (2012). The relationship between credit management practices and financial Performance of microfinances in Kenya.Unpublished MBA Dissertation, university of Nairobi.

Jeremiah, Bichanga (2014) .financial factors influencing performance of microfinances in Kenya. Retrieved from:URL:http://dx.doi.org/10.6007/IJARAFMS/v4-12/892 s 